\title{
Southern Ocean Expedition-Journey into the Hostile and
}

\section{Dangerous Environment}

\section{Hareef Baba Shaeb K* \\ Earth and Climate Science Area (ECSA), National Remote Sensing Centre (NRSC), India}

*Corresponding author: Hareef Baba Shaeb K, Earth and Climate Science Area (ECSA),

National Remote Sensing Centre (NRSC), Hyderabad 500625, India, Email:

babaphyiway@gmail.com

\section{Editorial}

'Roaring 40's, Furious 50's, and Screaming 60's' is what I first heard about southern ocean. These are caused by strong westerly winds that are caused by air being displaced from the Equator toward the South Pole and by the Earth's rotation in latitude bands that span $40^{\circ}-50^{\circ} \mathrm{S}$, $50^{\circ} \mathrm{S}-60^{\circ} \mathrm{S}$ and below $60^{\circ} \mathrm{S}$, respectively. With the medical history of severe asthma, Bell's palsy and leaving behind my children and family, I asked myself, is it worth going? Looking at the scientific challenges Southern Ocean (SO) is offering, scientist in me wants to take the risk. Southern ocean has a significant influence on global climate, biogeochemical cycles, biological production and Antarctic ice sheet. SO is responsible for the uptake and storage of heat and carbon which leads to slow down the atmospheric warming caused by green house effect. SO is responsible for $75 \%$ of ocean primary productivity north of $30 \mathrm{deg}$ south as it connects the deep and shallow layers of ocean providing a return path for nutrients. The main driving force for the transportation of heat and mass across SO is an eastward flowing Antarctic Circumpolar Current across which there are several frontal systems with rapidly changing water characteristic i.e., Agulhas Retroflection Front, Sub-Tropical front, Sub-Antarctic front, Polar Front, Southern Antarctic Circumpolar Current Front ; Southern Boundary of ACC and Antarctic Slope Front. Understanding the water mixing characteristics in this fronts is a challenge and the sea truth data available over SO is sparse in order to validate satellite and model observations. For a long time SO science was neglected by Antarctic science community; the rough ocean crossing was uncomfortable prelude. Whereas, southern ocean expedition challenge comes from making atmospheric and oceanic measurements in those extreme weather, high sea state and dangerous conditions for about 60days without touching the landmass. I carried instruments namely Greenhouse gas analyzer (which measures concentrations of atmospheric $\mathrm{CO}_{2}$, methane and water), Dust track monitor (which measures Particulate and total mass concentrations (PM2.5, PM1,PM10 and Total), Sun photometer and Ozonometer (which measures Aerosol optical thickness at 6 wavelengths namely $380 \mathrm{~nm}, 440,500,675,870$ and $1020 \mathrm{~nm}$, Columnar ozone and columnar water vapor). There were suit of atmospheric and oceanography instruments carried by my colleagues i.e Aethalometer, Radiosonde, Quartz Crystal Microbalance, Ozone analyzer, Multi-Axis Differential Optical Absorption Spectrometer, AWS, Micro Rain Radar, CTD , UCTD, XCTD, ADCP , Microstructure profiler, ARGO floats, SOCCOM floats, Fast Repetition Rate Fluorometer, Inherent Optical Profiler, which measure parameters such as black carbon, vertical profiles of meteorological parameters, rain rate, phytoplankton, temperature, salinity, water currents etc. The opportunity to get involved in operation of these instruments as a team member was very much exciting.

The 10th SOE (Prior to this 9 expeditions were carried out since 2004) was coordinated by National Centre for Antarctic and Ocean Research (NCAOR), Goa under the aegis of Ministry of Earth Sciences (MoES). The expedition started on $9^{\text {th }}$ December 2017 onboard chartered ice class vessel SA Agulhas from Port Louis, Mauritius. So, cabin found and gear unpacked, it was time for a quick buzz around the Agulhas to explore the ship. Passengers embarked, muster drill completed, and then Mauritius began to slip away behind us, and the impressive coastline began to slide past to port and starboard. For few, in which I am one of them, this was their first ocean 


\section{International Journal of Oceanography \& Aquaculture}

experience, putting the briefing theory into practice and feel the ocean waves. The expedition staff meeting was held in which scientific experiments to be done were discussed. The teams for every six hour atmospheric measurements (I was in 00:00 team!) and station duty were formed to ensure smooth measurements throughout the cruise. Foreseeing the effects of seasickness and ship balance difficulties, I have installed the instruments on the first day. For first few days I was in seasickness and was vomiting blood sometimes, at the moment I thought oceanographer should be the most respectable person in the universe.

We touched Roaring 40'son $14^{\text {th }}$ December and were welcomed by blessings of God (Rain!) and winds of 36 knots $(66 \mathrm{~km} / \mathrm{hr})$ against the winds of 11 knots $(20 \mathrm{Km} / \mathrm{hr})$ when we started. The wind was often at full gale force and with big Southern Ocean swells into which we were ploughing, the ship was at times slowed down and if going any faster was shuddering from stem to stern. Air temperatures (AT) and Sea surface temperatures (SST) dropped to about $16^{\circ} \mathrm{C}$. There were birds, petrels and Albatrosses of various sorts to make us feel we were not alone. Making oceanographic measurements by deploying instruments under the sea was challenging task. Ocean currents were trying to push away the instruments from measurement site and making sun photometer measurements (pointing the instrument at sun!) was other difficulty. There was a hectic work schedule associated with learning about different aspects of ocean. We reached Furious 50's on 21 $1^{\text {st }}$ December and $\mathrm{AT}$, SST and winds were $3^{\circ} \mathrm{C}, 4.5^{\circ} \mathrm{C}$ and 30 Knots $(55 \mathrm{Km} / \mathrm{hr})$ respectively. Celebrating Christmas in the ocean was unique and yes, Santa did bring gifts to us (secret Santa!). We crossed Antarctic convergence and reached Screaming 60'son $26^{\text {th }}$ Dec and AT, SST and winds were about $0.5^{\circ} \mathrm{C}$ and 9 Knots $(18 \mathrm{Km} / \mathrm{hr})$ respectively. Icebergs started appearing and a new study reveals that icebergs gradually release iron, a nutrient crucial for life, as they melt, enhancing the plant life in the water around them. We spotted first Adelie penguin swimming near the ship at about $65^{\circ}$ south and we celebrated New Year party which is an unforgettable experience that will definitely stand out from the same old New Year's Eve celebrations. We advanced further to about $67^{\circ}$ on $7^{\text {th }}$ Jan, 2018, looking at sea ice and icebergs (floating pieces of ice shelves from glaciers) which were moved by ocean currents and winds. AT was at $-1^{\circ} \mathrm{C}$, SST at $-0.5^{\circ} \mathrm{C}$ and winds were, 6 Knots $(11 \mathrm{Km} / \mathrm{hr})$ respectively. We were finally at the clearest (our measurements of aerosol optical depth and particulate matter concentrations were lowest), driest (measured columnar water vapor was lowest) and calmest weather anywhere on earth. On our return path at about $63^{\circ}$ south we could experience snowfall onboard the ship. On Jan $26^{\text {th }}$ we were at about $45^{\circ}$ South's and celebrated the republic day by hoisting the Indian national flag, yet another great experience. The most exciting, thrilling and rewarding (in terms of data collected) expedition came to an end on $4^{\text {th }} \mathrm{Feb}$, with captain guiding us smoothly through the narrow inner harbor entrance, turning to starboard and anchoring a stone's throw from the jetty and finally we were on land which we were longing to see while on board. Finally it's time to recall the inspired quote by Walter Munk, "The Einstein of the Oceans', 'It's important that you work on things that you care about and do a good job and not be too worried about consequences. Don't be afraid to get involved'. 